\title{
ON THE DESIRES OF THE HEART IN STUMP'S THEODICY
}

\section{LUKAS BENEDIKT KRAUS}

\author{
University of Innsbruck
}

In her recent book Wandering in Darkness, Eleonore Stump offers an account of the problem of human suffering which is strongly inspired by Thomas Aquinas's theodicy. Nonetheless, she argues that Aquinas's theodicy is incomplete since there is a kind of suffering which Aquinas does not deal with. Chapter 14 of her book is dedicated to filling this gap in Aquinas's theodicy.

According to Prof. Stump, a person can suffer not only by being kept from flourishing but also by losing her heart's desires. These two kinds of human suffering are distinct: A person can flourish even though some of her heart's desires are not fulfilled. Prof. Stump defines 'a person's heart's desire' as a 'particular kind of commitment on her part to something a person or a project - that has great value for her in virtue of her care for it but that need not be essential to her flourishing' (p. 7). Reminiscent of the well-known notion of a 'web of beliefs', she assumes the existence of a 'web of desires', whereas a 'desire of a person's heart is a desire that is at or near the center of the web of desire for her' (p. 7). Losing or not having the so desired objects causes a kind of suffering which is largely ignored by Aquinas's theodicy but which must be considered in order fully to account for the problem of suffering. In completing the thomistic account in this way, Prof. Stump is at pains to distinguish her answer to the problem of suffering from a view which she calls the 'stern-minded attitude', which advises the sufferer to give up the desires of his heart in order to avoid suffering.

In this paper, I want to show that there are at least two different possible interpretations of Prof. Stump's suggested solution. One of these interpretations is quite different from the stern-minded attitude, but 
seems unsuccessful. The second interpretation is more likely to solve the problem, but it is actually very close to the stern-minded attitude.

\section{THE PROBLEM}

The main strategy of Aquinas's theodicy is to relativize suffering to the period human beings spend in this world, in their earthly life before death. Compared with the everlasting afterlife, this period is only a small portion of the entire human life. Suffering in earthly life can be defeated by gaining sufficient benefit in the afterlife. God is justified in letting humans suffer if he provides this benefit in the afterlife and if suffering is the only available means for the sufferer to gain the benefit.

If you grant that this strategy works for the first kind of suffering, does it also work for the kind of suffering stemming from the loss of the desires of the heart? According to Prof. Stump, '[g]iven Aquinas's worldview, it is possible that the loss of flourishing in this life and the loss of the desires of one's heart in this life be a means to flourishing in the afterlife.' (p. 419) If we take on board Prof. Stump's distinction between the two kinds of suffering, then a remarkable asymmetry emerges in this statement: the two kinds of suffering, loss of flourishing and loss of the heart's desires, are redeemed by just one kind of benefit: flourishing in the afterlife. One can accept that the loss of flourishing could be defeated by flourishing. But what about the loss of the desires of one's heart? Can it be defeated by something completely different from it in kind?

One possible way to deal with the problem is merely to advise people to give up the desires of their heart and to 'focus their care only on their flourishing, their ultimate, spiritual flourishing' (p. 420). Prof. Stump calls this stance 'the stern-minded attitude' and shows that it has a long and remarkable tradition in Christian thought. She characterizes it as follows: 'The stern-minded attitude is unwilling to assign a positive value to anything that is not equivalent to or essential to a person's flourishing.' (p. 423)

For the stern-minded, suffering caused by losing one's heart's desires does not have to be defeated by some benefit. It simply vanishes when one gives up all one's heart's desires.

Prof. Stump rejects the stern-minded attitude as an 'unpalatable position' (p. 431). She argues instead that 'having a desire for things that are not necessary for flourishing is necessary as a means to flourishing' (p. 431). The stern-minded attitude therefore has 'something inhuman about it' (p. 431). 
For her, the question still remains open: 'what could one gain that would make it worth losing the desires of one's heart other than the desires of one's heart? But how could a person gain the desires of her heart by losing them?' (p. 433). Her ultimate answer leads to a more symmetrical version of the statement cited above: 'The suffering that stems from the loss of the heart's desire is defeated not just by flourishing but also by the gain of the heart's desires, even if in a refolded mode.' (p. 450)

So, contrary to the stern-minded attitude, one does not have to give up one's heart's desires in order to be rid of the suffering caused by the failure to attain them. Prof. Stump seems to claim that somehow one will get one's heart's desires fulfilled even if one loses them. It is dubitable that this claim can be held in a straight-forward manner. And so Prof. Stump has to try hard to argue for her view. Is she successful?

\section{TWO DIFFERENT STRATEGIES}

As I stressed before, one of the main strategies of Aquinas's theodicy is to relativize suffering to the small period of one's earthly life to the hope for a redeeming benefit in the afterlife. If the only benefit which defeats suffering stemming from the loss of one's heart's desires is to have just these desires fulfilled, then this kind of relativization is not possible. On a thomistic view, only what has a rational soul can have an afterlife and enter heaven. In heaven the rational souls will share in the fullest form of happiness which consists in a post-mortem knowledge and understanding of God (beatitudo). This clearly theocentric notion of happiness makes it very unlikely to have the earthly things or animals we love and have set our hearts on in heaven for this might reduce our dedication to the union with God. ${ }^{1}$ Therefore, many desires cannot be fulfilled in the afterlife, at least if we talk about desires for material things, animals or projects typical for our earthly existence. So the problem cannot be solved by appeal to the afterlife. But in this case, the strongest argument of Aquinas's theodicy is no longer applicable. Looking at the misery of earthly life, of so many human beings who die without having their heart's desires fulfilled, it seems hopeless to find a way to see how this suffering could be redeemed in earthly life.

Yet Prof. Stump tries to find such a way. She does so by adopting and modifying Aquinas's idea of relativization, which is now not to two

${ }^{1}$ See also Brian Davies, 'Happiness', in Brian Davies and Eleonore Stump, The Oxford Handbook of Aquinas (Oxford: OUP, 2012), pp. 227-237. 
different portions of a person's life but to 'two different layers of depth in the heart's desires themselves' (p. 449). The idea is that heart's desires can be ranked in order of subjective value. On this scale of subjective value the 'things that have deeper subjective value for a person can be the source of value for other things that have subjective value for him' (p. 437). According to Prof. Stump, 'a heart's desire can change its configuration in virtue of its being interwoven into something deeper among the desires of the heart.' (p. 446)

In the subsequent course of the argument, she seems to pursue two different strategies which she does not clearly distinguish from each other. The first strategy is based on the idea that if a desire is not fulfilled in its original form, it could be fulfilled in an altered form. A reshaped desire can be deeper on the scale of subjective value, and so the grief over the loss of it in its original form is redeemed by gaining it in its reshaped, more valuable form. The second strategy starts with the Augustinian view that there is 'a connection between other desires of the heart and the innate deepest heart's desire for God and shared union with God' (p. 442). She then claims that, by interweaving a heart's desire into that deepest heart's desire for God, in the event that this heart's desire is lost, the character of suffering generated is altered. The grief over the loss is then redeemed by having what one most deeply wants (i.e. shared union with God) and by being able to 'wait in trust' (p. 446). In the next two paragraphs, I will examine both strategies in more detail.

\section{THE ULTIMATE FULFILLMENT OF THE HEART'S DESIRES}

Let us begin with the first strategy, which promises a fulfilment of the heart's desires, even if in an altered form. Prof. Stump admits that she has 'no idea how to individuate heart's desires', but she insists on the possibility for a heart's desire 'to be radically reconfigured and still remain the heart's desire it was' (p. 445). In a footnote on that issue, she refers to a typological explanation which consists in comparing the reconfiguring of the heart's desires with the refolding of proteins. The refolded protein is still the same protein, even though it has altered its structure radically. Prof. Stump omits a deeper analysis of this point, but she gives several examples of cases where a refolding and the ultimate fulfilment of the heart's desires have taken place. She prominently refers to the life of Victor Klemperer, who had to give up his desire for writing a study of French literature in the years of the National-Socialistic regime in Germany and author the famous Klemperer diaries instead. She writes: 
It is hard not to believe that Klemperer would have greatly preferred being the author of the Klemperer diaries than of the critical work on French literature he thought it was his heart's desire to write. [...] in Klemperer's case [...] intuitively it seems that there are two configurations of one single heart's desire, just as there can be two configurations of one and the same protein; and one of these configurations is deeper, closer to the center of the web of desire, than the other. (p. 443)

But is it really one single heart's desire? If you look at it in a more abstract way, you can recognize that what is described falls under the same genus, which is in this case something like 'being the author of a great book'. But falling under the same genus is usually not enough to guarantee identity. The identity of a heart's desire seems to be a matter of how much detail is needed to describe the object of a heart's desire. It is surely true that you can always reach a level of description which is abstract enough to identify heart's desires which differ on a less abstract level. But this strategy looks arbitrary. You end up stating that, after a person had experienced something good in her life, it is precisely this which was her heart's desire the whole time, no matter what it was and no matter what she had thought her heart's desire was.

For me, it seems natural to individuate desires by their objects. If two desires have different objects (i.e., if they are desires for different things), then they cannot be identical. It is not enough that the things desired fall under the same genus. In Klemperer's case, we talk about two different things that are desired, and therefore we talk about two different desires. Klemperer only had the desire to write his study of French literature, he perhaps never had the desire to publish the diary. It was published many years after his death. ${ }^{2}$ It is a good thing, and one can imagine that Klemperer himself would be glad to know he is the author of this book, but it has little to do with the heart's desire which Klemperer had while alive. It is important to note that Klemperer actually did write his study of French literature after the war. ${ }^{3}$ Thus, his heart's desire to write this book was fulfilled! There is no need to seek a substitute in this case. If you

${ }^{2}$ Victor Klemperer, Ich will Zeugnis ablegen bis zum letzten. Tagebücher 1933 - 1945 (Berlin: Aufbau-Verlag, 1995). Klemperer himself used his diaries to write a study of the language of the national-socialists: Victor Klemperer, LTI - Notitzbuch eines Philologen (Berlin: Aufbau-Verlag, 1947).

${ }^{3}$ Victor Klemperer, Geschichte der französischen Literatur des 18. Jahrhunderts (Berlin: Deutscher Verlag der Wissenschaften, 1954 - 1966). Prof. Stump shortly mentions the existence of this book in an indirect citation in the first chapter (p. 12, footnote 31 [p. 488]). 
still claim that his heart's desire was fulfilled by being the author of the diaries, you have to deal with the fact that this single desire was fulfilled twice. The analysis of the individuation of heart's desires becomes a very confusing task then.

What you can say is that Klemperer's grief over being kept from his literary work for so many years is redeemed by being able to write a different great book during those years. The two desires to write these two books are linked in this way: The suffering stemming from keeping him from his work on the literary book is a necessary condition for being able to write the diaries. So the suffering ultimately leads to something good for the sufferer in this case. The two projects are intimately related, but there is no need to identify them.

You can imagine a case in which Klemperer died before finishing his literary work but knowing that his diaries would be published after his death. In this case, you could say that the suffering stemming from not having what he desires is redeemed by being able to write this other great book instead. The suffering is not redeemed by ultimately gaining what he desires but by gaining something different that consoles him. This consolation is only possible if he finally gives up his original heart's desire, at least when he discovers that he will soon die.

There might be cases in which hearts' desires are fulfilled. And there might be cases in which the fulfilment comes in a slightly different form. But the really problematic cases are those with a great difference between the original heart's desire and what is finally gained. In these cases it is problematic to talk about the same desire being fulfilled. Consequently, in these cases, redemption of the suffering stemming from the loss of a heart's desire can only occur through giving something up. In my view, this means giving up the original heart's desire. And even Prof. Stump seems to draw a similar conclusion in talking about the loss of the heart's desires in their original form and the suffering stemming from that loss (p. 446). So she admits that something about the original heart's desire will never be attained. Claiming that people who suffer from heartbreak have what they wanted does not seem to be appropriate.

As far as I can see, Prof. Stump does not argue satisfactorily that suffering stemming from the loss of the heart's desires is redeemed by gaining these desires in earthly life, even if in a different form. The crucial point is the missing analysis of the individuation of the heart's desires. Without such an analysis, it is not clear what 'refolding of heart's desires' means. Stating an analogy between heart's desires and 
proteins is surely not enough to explain it. And the most prominent example given, that of Klemperer, is at least problematic. So, what I identified above as a first strategy is not an acceptable solution to the problem of the loss of the heart's desires.

\section{HOPE, AND WAIT IN TRUST}

Prof. Stump does not pursue this strategy in the course of chapter 14 . Instead, she initiates discussion of a different strategy. This strategy still deals with a 'refolding' of the heart's desires, but now the focus is not on what the desires are desires for. What is stressed is the function that the heart's desires have in a developing relationship between God and the person whose desires these are. Prof. Stump says:

If a person takes God as her deepest heart's desire, all her other heart's desires, including desires for a project, can refold, can reshape without losing their identity, by being woven into that deepest desire. If that happens, then the other things she had her heart set on become gifts, gifts had or hoped for, or even gifts lost or not given. (p. 445)

It is now of no further importance whether a heart's desire is in the end attained or lost. There is only one exception: the deepest heart's desire, i.e., the desire for God and shared union with God. All the other heart's desires, considered as gifts from God, play a prominent role in the dynamic development of this relationship with God. A person who has shared union with God has her deepest heart's desire fulfilled. She will not suffer complete heartbreak: 'Things do not fall apart for her' (p. 449). But this is still not the whole story. Prof. Stump writes:

[...] refolding the heart's desires by interweaving them with a deepest desire for God alters the character of the suffering over the loss of them in their original form. When one of those in union is a perfectly loving God, the human person in that union can wait in trust even while he is grief-stricken over the loss or absence of something he had his heart set on. In such circumstances, both the waiting and the trust become a kind of giving back which is part of the mutuality of love. (pp. 446-447)

The shared union with a perfectly loving God lets a person live in trust and hope for the fulfilment of the desires of her heart. The reason to keep up that hope is her belief in a loving God. Here Prof. Stump refers to Aquinas's account of love: if God loves that person, then he cares about what she cares about. 'The alternative is to suppose that God is unloving.' (p. 444) 
Is this second strategy a satisfying solution to the problem of the lost desires of the heart? I think it is, if you grant that the original thomistic strategy, which is based on hope for flourishing in the afterlife, is successful. The reason is that what I call Prof. Stump's second strategy is also essentially based on hope for flourishing in the afterlife.

To see this, let us look more closely at the 'refolding' of the heart's desires into gifts from God. In contrast to the first strategy, the problem of individuation of desires does not arise here, because the thing desired clearly remains the same before and after the refolding. What is changed by refolding a heart's desire is the function of that desire in developing the person's relationship with God: what is desired is now desired as a gift from God. The heart's desire is intimately linked to the deepest heart's desire for God. This deepest heart's desire is equivalent to what is of highest objective value. Here Prof. Stump agrees with Aquinas and Augustine: 'For Aquinas as for Augustine, it is possible for a human person to take as her deepest heart's desire the very thing that is also her greatest flourishing - namely, God and shared union with God.' (p. 441) For a believer, union with God is ultimately reached in the afterlife. So the reason why a believer can trust that his deepest heart's desire will be fulfilled is his hope for its ultimate fulfilment in the afterlife.

Concerning the other desires of the heart, Prof. Stump gives a reason how waiting in trust for their fulfilment becomes possible: it is a consequence of the belief in a loving God. But what kind of fulfilment can be faithfully and reasonably waited for? As shown in the preceding paragraph, the fulfilment in question cannot be a literal fulfilment of the desires in their original form. What can be waited for is a fulfilment in a refolded form, i.e., as a gift from God. And gifts can be 'had or hoped for, or even [...] lost or not given' (p. 445), as cited above. Here, Prof. Stump seems to suggest that even a gift hoped for, lost, or not given is a case of gaining a heart's desire, because, whichever of these outcomes obtains, it brings the person's relationship with God to develop and therefore brings the person nearer to the state of shared union with God. And since shared union with God is equivalent to a person's greatest flourishing, what is really hoped for in waiting for the fulfilment of the heart's desires is the ultimate flourishing in shared union with God. Another reference to the link between obtaining heart's desires as gifts from God and obtaining ultimate flourishing can be found in the claim that gifts have to be 'given back' in some sense: 
Even the thing wanted as gift becomes wanted as something to be given back - not in the sense of being rejected, as the stern-minded attitude might suppose, but in the sense of being interwoven into the flowering of a life made into a gift for the person who is one's deepest heart's desire. (p. 447)

So, if every gift from God has to be given back and if 'giving back the gift' means using it for flourishing in shared union with God, it is now clear that hope for gaining a heart's desire as a gift from God is nothing but hope for flourishing in honour of God. The heart's desire itself is just a means to obtaining this object of deeper desire. And as a means it can in principle be exchanged by a different means to obtain the object of the same deeper desire. Furthermore, if the final aim of all hearts' desires is flourishing, then the loss of a heart's desire can be defeated by gaining ultimate flourishing in the afterlife. And this is exactly the way human suffering can be redeemed according to Aquinas.

If you grant that the original thomistic strategy is successful, as Prof. Stump does, then her (second) strategy concerning the suffering caused by losing the desires of one's heart is successful, too.

\section{THE DIFFERENCE TO THE STERN-MINDED ATTITUDE}

Prof. Stump goes to great lengths to distinguish her view from the sternminded attitude. We can now see why: the view she finally advances is in fact not very far from the stern-minded view itself. What exactly is the difference between Prof. Stump's second and final account on the problem of lost desires of the heart and the view she repudiates as stern-minded?

There are two closely related ways in which the two positions differ: At first, on Prof. Stump's view, hearts' desires are not completely without value. On the contrary, considered as gifts from God, they have an 'added value' (p. 444). The second difference is the attitude of trust in the final gain of the heart's desires as gifts from God, which is said to be a consequence of believing in a loving God. The stern-minded give up their heart's desires, whereas followers of Prof. Stump's view continue waiting in trust.

Both differences between the stern-minded view and Prof. Stump's view have their roots in different views concerning the role that the objects one's heart can desire play in one's relationship with God. For the stern-minded, maintaining one's heart's desires disturbs this relationship: A person with heart's desires loves something that is not God and therefore is in danger 
of committing idolatry by replacing God with that beloved object. If she does not receive the loved object, or if it is taken away from her, she has to suffer heartbreak. In consequence, to avoid suffering which cannot be redeemed, it is better not to love anything other than God. In Prof. Stump's view, hearts' desires can peacefully coexist with or even strengthen one's relationship with God - but only as long as one regards the desired objects as gifts from God. God is the first and foremost object of love, but this does not keep one from loving other persons, things, or projects. On the contrary, these other objects are loved just because they are recognized as gifts from a loving God. If the loved objects are lost, one certainly has to suffer, but this suffering is redeemed because the relationship with God remains intact or even grows.

But even in this description of the difference between Prof. Stump's view and the stern-minded view, one can recognize their remarkable similarity: On both views, all hope of redemption from suffering is ultimately based on the sufferer's relationship with God. This is the only deepest heart's desire. Choosing God as one's deepest heart's desire is the only way to avoid idolatry and complete heartbreak. If one attaches a high subjective value in earthly life to things other than God, there will be a time when one finally has to give up these good and valuable things: when one's life comes to an end. Then the hope for fulfilment of the heart's desires can change into what it has always been for a believer: the deep desire for flourishing in union with God. In this sense, it is possible to maintain hope for the fulfilment of one's heart's desires. And that is why I think a synthesis of both views is possible: realizing that most of our heart's desires have to be given up in the end, without giving up the attitude of hope and trust in God.

A prominent witness to this attitude is the German pastor and theologian Dietrich Bonhoeffer, who was imprisoned by the National Socialists for two years and finally executed. From prison, he managed to write letters to his family and his friends, in which he described his thoughts about his situation, and his faith and trust in God. In one of these letters, he writes: 'Es gibt erfülltes Leben trotz vieler unerfüllter Wünsche'4 (You can find personal fulfilment in spite of many unfulfilled desires). In the same letter, Bonhoeffer emphasizes that this attitude should not be understood as resignation:

${ }^{4}$ Dietrich Bonhoeffer, Widerstand und Ergebung. Briefe und Aufzeichnungen aus der Haft (München: Kaiser, 1964), p. 162. 
Im übrigen muß ich in notwendiger Ergänzung zu dem Vorigen sagen, daß ich mehr denn je daran glaube, daß wir auch der Erfüllung unserer Wünsche entgegengehen und wir uns keineswegs der Resignation hinzugeben haben. ${ }^{5}$

(In addition to what I said above, I cannot avoid stating that I believe more than ever that we are equally approaching the fulfilment of our desires and that we should not abandon ourselves to resignation.)

Acknowledgement. This publication was made possible through the support of a grant from the John Templeton Foundation, grant \#15571 ("Analytic Theology"). The opinions expressed in this publication are those of the author and do not necessarily reflect the views of the Templeton Foundation.

${ }^{5}$ Ibid., p. 163. 